\title{
広告媒体の地域性と情報偏在 -2地域3媒体モデルによる解析一
}

\author{
地主 遼史 1 ・井料 隆雅 2 \\ 1学生会員 神戸大学 大学院工学研究科（†657-8501 神戸市灘区六甲台町1-1） \\ E-mail: ryoji_jinushi2@stu.kobe-u.ac.jp \\ 2 正会員 神戸大学教授 大学院工学研究科（同上） \\ E-mail: iryo@kobe-u.ac.jp
}

\begin{abstract}
消費者が全ての店舗の情報を保持しているとは限らず，そのような情報の偏りは店舗選択等に大きく影 響するだろう。本研究ではこの情報の偏在の解決を地域商店街等復興の糸口ととらえ，その一因の候補と して広告に注目した。企業による広告発信を扱う既存のモデルのうち，消費者が広告を受け取る量の限界 を考慮したモデルを活用する．離散的な地域と広告媒体の対象範囲の違いという2つの空間的な要素を組 み込み, 数值計算による分析を行った。料金上昇を対象範囲の狭い媒体のみに行うと, 対象範囲内で（比 較的）収益を上げる企業の認知度が（地域を跨ぐ企業に比べ）低下し，かつ発信の効率低下を意味する混 雑悪化を招く場合があることを示した，あわせて，媒体が複数ある場合，限定的な条件下で包括的な料金 上昇がパレート改善を達成することを証明した。
\end{abstract}

Key Words : advertising, congestion, information asymmetry, information overload, noise effect

\section{1. はじめに}

消費者は全ての店舗の情報を持っているとは限らない 所持している情報を基に消費者は行動を決めるため，情 報の偏りは行動に影響を与えうる．何らかの理由で情報 が伝播されない企業やサービスは選択肢から外れるだろ う。例えば地域の個人商店はチェーン店に比べそのよう な傾向を持つと予想される，林と井料 ${ }^{1}$ は同様の問題意 識から消費者の持つ情報について実証研究を行い，予想 と整合的な結果を報告している.このような情報の偏り を発生させるメカニズムに関する研究は地域商店街の振 興などの実務的な課題の解決に寄与する可能性があろう. 本研究では消費者に情報が伝播する手段の一つである 広告に注目する。広告は消費者と企業間に存在する情報 の偏在を緩和する機能があり，消費者が多様なサービス を認識するために有用である。しかし一方で広告の利用 が一部の企業に偏り，新たな情報の偏在が生まれる可能 性がある．本研究でいう情報の偏在を，一部の企業の情 報が消費者に過剰に供給され他方で残りの企業の情報が 消費者に全く供給されない状態と定義する，そのような 状態は異なる規模の商圏を持つ企業が混在する状況にお いて顕著に現れるかもしれない. 例えば林・井料が報告 したような認知度の差異が普遍的であり，それが広告に
よる情報発信の偏りを一因とするのであれば，偏りを是 正することは地域の小規模店舗の認知度向上に繋がる. 広告はサービスを提供する側が自律的に行うものであり， 経済学に基づく定式化が可能である. 広告を数理的に分 析し，情報伝播の傾向を検討することは地域商店街の活 性化を図る上で意義がある。

広告の数理的解析は制度としての広告の研究の範疇に 入る. 制度としての広告については経済学に豊かな先行 研究がある．特に情報の偏在と消費者の行動，広告の関 係は，例えばStigler ${ }^{2}$ やNelson)など情報の経済学の初期か ら研究されている．彼らの主張の一つとして，情報の偏 在が完全競争を阻害することが挙げられる。 Bagwell $\left.{ }^{4}\right)$ は 広告に関する（主に）20世紀に行われた経済学の研究を 包括的にレビューしている，論文内で紹介されている Noise effectに注目したい. Noise effectは既存企業が広告を 大量に打つことで参入者の情報が埋もれてしまう効果を 意味する. 本研究にとって重要なことは, Noise effectの 影響で（採算が取れるという意味で）本来認識されるべ き企業や店舗が認識されない可能性である，地域の小規 模店舗はNoise effectの影響で広告を利用できていないか もしれない.なおNoise effectの議論は消費者が処理でき る広告の量に限界があることを前提にしている.

大量の情報に直面した人間が情報を処理しきれないこ 


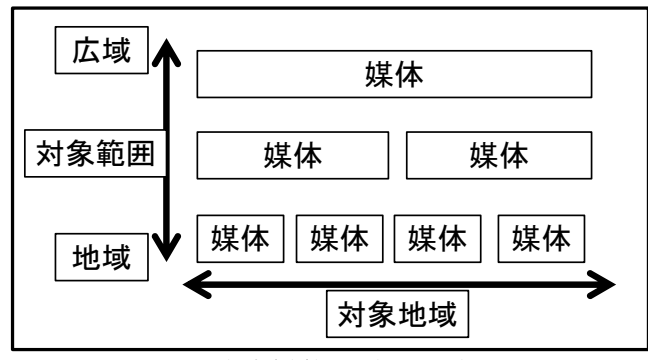

図-1 広告媒体の階層構造の例

と（Information overload）は学際的に研究されてきた（cf. Eppler \& Mengis ${ }^{5)}$ ) ． 近年経済学では受け手側の容量（以 下受信容量）を考慮した発信のモデル化が行われている Van Zandt ${ }^{6}$ は発信側が受け手を選択できる状況における 一方的な発信を定式化した. Anderson \& de Palma ${ }^{7}$ は受け 手側が受信容量を操作できる場合のモデル化を行ってい る.またAnderson \& de Palma ${ }^{8}$ は受け手側の差異と挙動を 捨象した上で，送り手側に産業間の競争と産業内の（価 格）競争がある場合を研究している. 更にAnderson \& de Palma' ${ }^{9)}$ 同様の簡略化で送り手側が複数回の発信を行え るモデルを検討している. 先行研究の背景には以下の問 題意識がある．広告の発信総量が消費者の認識できる広 告の量を超えると, 消費者に認識されない無駄な発信が 発生し，結果として発信の効率が低下寸る。このような 広告における情報の混雑現象は道路のボトルネックにお ける渋滞現象と似ている。道路淽滞と同様に，広告の混 杂隹現象もパレート劣位に陥ることがあり，料金の上昇な どにより優位な状況を実現できる可能性がある. 本研究 でも以上の考え方にしたがい，情報の偏在とその原因と なる情報の混雑に注目し，料金上昇の影響を検討寸る.

店舗の認知度と商圏の関係を広告の側面から検討する ためには，モデル内に地域の概念と異質な広告媒体が必 要である. 例えば，チェーン店の存在下で地域商店街の 活性化を図ろうとする際には，サービスの商圈の広さや 広告媒体の地理的な影響範囲の広さの差異は無視できな い. 広告媒体を対象範囲で区分すると, 例えば図-1のよ うな階層構造を構成する.このような状況（例えば地域 情報誌と全国誌による広告発信）の分析には，異なる影 響範囲を持つ広告媒体と, 異なる広さの商圈を持つ企業 を，モデルに明示的に組み込む必要がある．広告の混雑 現象を扱った先行研究では広告媒体の異質性は考慮され ていないため, これは本研究における拡張になる.

本研究では2つの対象地域に情報を発信する3つの広告 媒体を想定したモデルを構築し，そのナッシュ均衡解を 求める.またモデル内の広告料金を変化させた場合の情 報の混雑や偏在の変化を検証する．2章ではモデルの定 式化と均衡解の導出を行う。3章ではパラメータを与え て均衡解を比較し, 料金上昇がもたらす情報混雑の変化 や各企業の認識率への影響を見る，4章では，包括的な
料金上昇によって限定的な条件下でパレート改善が実現 することを示し，5章で結論を述べる.

\section{2. モデルの定式化と均衡解の解法}

\section{(1) モデルの定式化}

ここでは Anderson \& de Palma')のモデルと同様の設定を 基礎に，地域と媒体の異質性を考慮したモデルを定式化 する. 対象地域 $i=(1,2)$ にサービスを提供する企業群を 考える. 各企業は消費者に伝えたい情報を 1 つだけ持つ とする．企業は消費者に情報を複数回発信できる．発信 が 1 度でも消費者に受信されれば便益を得る．便益の量 は受信回数が 1 回以上であれば回数によらず一定である. 各企業が地域 $i$ に発信を行い, 受信されることによって 得る便益は $\pi^{i}\left(\theta^{i}\right)$ と表す. $\theta^{i} \in(0,1)$ は企業を区別する ためのラベルであり，これを企業の地域 $i$ に対する選好 と呼ぶ. 企業群内で地域 $i$ から得る便益の小さい順に 0 から 1 の值を各企業に付ける. 例えば $\theta^{i}=0.5$ であれば 地域 $i$ からの便益が中央值の企業である. 今回は地域 1 , 2いずれへの選好も 0 から 1 のあいだで一様の密度で分 布すると仮定する。 また便益と選好の関係について $\pi^{i}\left(\theta^{i}\right)=\bar{\pi}^{i} \theta^{i}$ と線形の関係を仮定する. モデル内で, 地域 $i$ に存在する消費者は受信容量 $\phi^{i}$ 個の発信しか受信 できない. 広告には各地域に発信を行う地域媒体 1,2 と両方の地域に発信を行う広域媒体 $L$ の 2 種類 3 媒体を 想定し，それぞれの単位発信当たりの料金を $\gamma^{1}, \gamma^{2}, \gamma^{L}$ と外生的に与える. 料金は Anderson \& de Palma ${ }^{7}$ と同様に, 社会的費用（の近似）と解釈する。 また発信が受信され る確率はどの媒体でも同一地域内で等しいと仮定する. 各媒体において全企業が行う発信数の総和を総発信数 $n^{1}, n^{2}, n^{L}$ と置く. 地域 $i$ においてある 1 回の発信が受 信される確率を受信率と呼ぶことにする. これは

$$
\rho^{i}=\frac{\phi^{i}}{n^{i}+n^{L}}
$$

と計算できる.今回は混雑状態における情報の偏在に注 目するために, $0<\rho^{i} \leq 1$ となる場合のみを分析対象と する. $\boldsymbol{\theta}=\left(\theta^{1}, \theta^{2}\right)$ を持つ企業は利潤（二便益一費用）を 最大化するために地域媒体による発信 $l^{1}(\boldsymbol{\theta})(=0,1,2, \ldots)$, $l^{2}(\boldsymbol{\theta}) \quad(=0,1,2, \ldots)$ と広域媒体による発信数 $l^{L}(\boldsymbol{\theta}) \quad(=0,1$, $2, \ldots)$ を決定する. 以降発信数を表記する場合簡便のため 引数 $\boldsymbol{\theta}$ の表記を省略する.

全ての企業が利潤を最大化する状態, すなわち, 全て の企業の $l^{1}, l^{2}, l^{L}$ が, 最適化問題

$$
\max _{l^{1}, l^{2}, l^{L}} \sum_{i=1}^{2}\left(\bar{\pi}^{i} \theta^{i}\left(1-F\left(l^{i}, l^{L}, \rho^{i}\right)\right)-\gamma^{i} l^{i}\right)-\gamma^{L} l^{L}
$$

の解である状態を均衡状態（ナッシュ均衡） と定義する. またここで $F\left(l^{i}, l^{L}, \rho^{i}\right)=\left(1-\rho^{i}\right)^{l^{i}+l^{L}}$ と定義する.これは $l^{i}+l^{L}$ 回の発信が一度も受信されない確率である. した 
がって $1-F\left(l^{i}, l^{L}, \rho^{i}\right)$ は企業の情報が一度でも受信され る確率を示寸. 今回は均衡解における発信数を $l^{l^{*}}, l^{2^{*}}$, $l^{L^{*}}$ と表記する.

\section{（2）ナッシュ均衡と等価な条件の導出}

広告料金の大小関係によって $l^{1^{*}}, l^{2^{*}}, l^{L^{*}}$ のうちいくつ かは必ず0になる。このことを以下で示す．まず， $\gamma^{1}+\gamma^{2} \leq \gamma^{L}$ のときは，広域媒体を用いた1回の発信の費 用に比べて，各地域一地域媒体で1回ずつ発信する費用 のほうが小さいかせいぜい等しい. よって任意の脰しつ いて $L^{L^{*}}=0$ とできる. 次に，そうでない場合，すなわ ち, $\gamma^{1}+\gamma^{2}>\gamma^{L}$ の場合を考えよう. 仮に $l^{1} \geq l^{2} \geq 0$ で

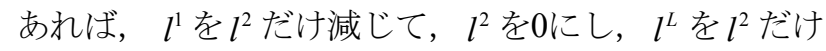
増やせば，発信費用を $\left(\gamma^{1}+\gamma^{2}-\gamma^{L}\right) l^{2}$ だけ減らせるか, あるいはせいぜい不変である。，一方で，それ以外の場合， すなわち $l^{2} \geq l^{1} \geq 0$ の場合も同様の方法で発信費用を $\left(\gamma^{1}+\gamma^{2}-\gamma^{L}\right) l^{1}$ だけ減らせるか，あるいはせいぜい不変 である. したがって, $\gamma^{1}+\gamma^{2}>\gamma^{L}$ のときには任意の $\boldsymbol{\theta}$ について $l^{*}=0$ または $l^{2^{*}}=0$ となる．以上のことは

$$
\begin{aligned}
& \gamma^{1}+\gamma^{2} \leq \gamma^{L} \Rightarrow l^{L^{*}}=0 \\
& \gamma^{1}+\gamma^{2}>\gamma^{L} \Rightarrow l^{l^{*}}=0 \text { or } l^{2^{*}}=0
\end{aligned}
$$

とまとめられる。 なお， $\gamma^{1}+\gamma^{2} \leq \gamma^{L}$ の場合はAnderson \& de Palma9)のモデルを地域ごとに独立に適用寸れば解ける ことに注意したい．以降では $\gamma^{1}+\gamma^{2}>\gamma^{L}$ の場合につい てのみ考える.

広域媒体の発信数を固定し，「 $l^{1}$ または $l^{2}$ が1個増加 すると利潤が増加する」という命題が成立するために $\boldsymbol{\theta}$ が満たす心゙き条件を求める. $\gamma^{1}+\gamma^{2}>\gamma^{L}$ および式(3)よ り，均衡解を探索する目的においては $l^{1}=0$ または $l^{2}=0$ として差し支えない. まず, $l^{2}=0$ であれば, 特定の選好 $\boldsymbol{\theta}$ を持つ企業にとって, 地域媒体1の発信数 を $l^{1}-1$ から $l^{1}$ まで増やしたときに利潤が増えるかせい ぜい等しい条件は，式(2)の目的関数の差分を計算する ことにより

$$
\theta^{1} \geq \frac{\gamma^{1}}{\bar{\pi}^{1} F\left(l^{1}-1, l^{L}, \rho^{1}\right) \rho^{1}} \text { if } l^{2}=0
$$

となる、なお，この計算には

$$
\begin{aligned}
& F\left(l^{i}-1, l^{L}, \rho^{i}\right)-F\left(l^{i}, l^{L}, \rho^{i}\right) \\
& =\left(1-\rho^{i}\right)^{l^{i}+l^{L}-1}-\left(1-\rho^{i}\right)^{l^{i}+l^{L}}=\rho^{i} F\left(l^{i}-1, l^{L}, \rho^{i}\right)
\end{aligned}
$$

の関係式を用いた．同様に $l^{1}=0$ として

を得る。

$$
\theta^{2} \geq \frac{\gamma^{2}}{\bar{\pi}^{2} F\left(l^{2}-1, l^{L}, \rho^{2}\right) \rho^{2}} \text { if } l^{1}=0
$$

$l^{1}$ または $l^{2}$ が任意の非負の值を取る場合に，広域媒 体の発信数が $l^{L}-1$ から $l^{L}$ に増加することで利潤が改善 寸る $\boldsymbol{\theta}$ の範囲を求める．なお， $\gamma^{1}+\gamma^{2}>\gamma^{L}$ および式(3)
より，均衡解を探索する目的においては $l^{1}=0$ または $l^{2}=0$ として差し支えない. 先に $l^{2}=0$ の場合につい て計算する. 広域媒体の発信数を $l^{L}-1$ から $l^{L}$ に増やす ことに利潤が増えるかせいぜい変わらない選好 $\boldsymbol{\theta}$ を持つ 企業を考える. 式(2)の目的関数の差分を計算すれば

$$
\begin{aligned}
& \theta^{2} \geq \frac{\gamma^{L}-\gamma^{1}}{\bar{\pi}^{2} \rho^{2} F\left(0, l^{L}-1, \rho^{2}\right)} \text { if } l^{1}>0, l^{2}=0 \\
& \sum_{i=1}^{2} \bar{\pi}^{i} \theta^{i} \rho^{i} F\left(0, l^{L}-1, \rho^{i}\right) \geq \gamma^{L} \quad \text { if } l^{1}=l^{2}=0
\end{aligned}
$$

を得る. 次に, $l^{2}=0$ の代わりに $l^{1}=0$ として同じ計算 を行うと，

$$
\theta^{1} \geq \frac{\gamma^{L}-\gamma^{2}}{\bar{\pi}^{1} \rho^{1} F\left(0, l^{L}-1, \rho^{1}\right)} \text { if } l^{1}=0, l^{2}>0
$$

および式(8)を得る。

式(4)，(6)，(7)，(8)，(9)を組み合わせれば，広域媒体 の発信数 $l^{L}$ がある值から1個だけ増加するときに利潤が 改善する $\boldsymbol{\theta}$ の範囲を $l^{1}$ または $l^{2}$ をちえることなく決定 できる. 所与の $l^{L}$ に対して $l^{1}=l^{2}=0$ という条件が利潤 を最大する場合を考える. 式(4)より，このときの $\theta^{1}$ の 範囲は

$$
\theta^{1} \leq \frac{\gamma^{1}}{\bar{\pi}^{1} F\left(0, l^{L}, \rho^{1}\right) \rho^{1}}
$$

となる．これは式(8)の $\theta^{1}$ が満たすべき範囲を示してい ることにほかならない．同様に式(6)より

$$
\theta^{2} \leq \frac{\gamma^{2}}{\bar{\pi}^{2} F\left(0, l^{L}, \rho^{2}\right) \rho^{2}}
$$

も式(8)の $\theta^{2}$ が満たすべき範囲を示す．よって式(8), (10), (11)に囲まれる三角形の領域が求める範囲の一部になる

（図-2の領域 A）。次に, 所与の $l^{L}$ に対して $l^{1}=0, l^{2}>0$ という条件が利潤を最大寸る場合を考える. このときは式(6)と(9)が成立する. $\theta^{1} \leq 1$ とあわせてこれ は図-2の領域Bに相当する. 最後に, 所与の $l^{L}$ に対して $l^{1}>0, l^{2}=0$ という条件が利潤を最大寸る場合を考える. このときは式(4)と(7)が成立する. $\theta^{2} \leq 1$ とあわせてこれ は図-2の領域Cに相当する. 3つの領域を重㸚合わせるこ とにより, 広域媒体の発信数が $l^{L}-1$ から $l^{L}$ に増加する ときに利潤が改善する $\boldsymbol{\theta}$ の範囲を定めることができる. この範囲を以降では集合 $A_{L}\left(l^{L}\right)$ で示す. $A_{L}\left(l^{L}\right)$ は $l^{L}$ が 大きくなればなるほど狭まる，正確には，

$$
A_{L}\left(l^{L}\right) \supseteq A_{L}\left(l^{L}+1\right) \text { for any } l^{L} \geq 1
$$

が成立することは容易に確かめられる，よって，ある $\boldsymbol{\theta}$ における均衡解における広域媒体の発信数（すなわち, 最適化問題(2)の解となる発信数) $l^{L^{*}}$ は,

$$
\boldsymbol{\theta} \in A_{L}\left(l^{L^{*}}\right) \text { and } \boldsymbol{\theta} \notin A_{L}\left(l^{L^{*}}+1\right)
$$

の解として一意に求めることができる.

最終的に均衡解は図-3および図-4のように図示できる. 図-3の領域内の数字は $l^{L^{*}}$ を, 図-4の右下の領域内の番 


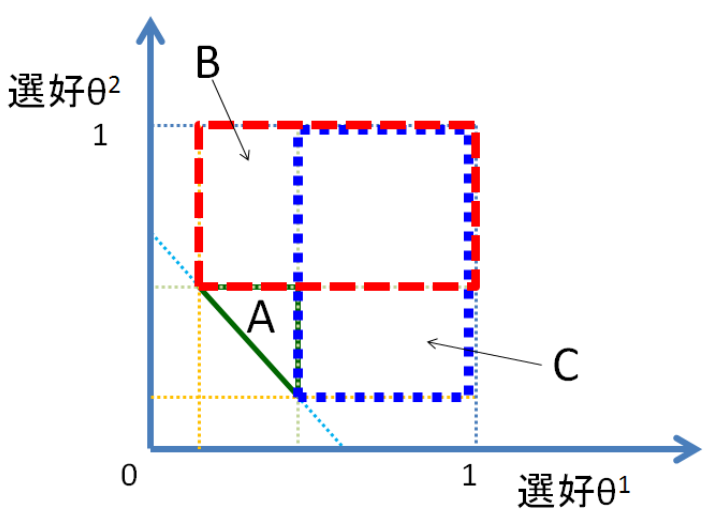

図-2 $l^{L}$ の領域

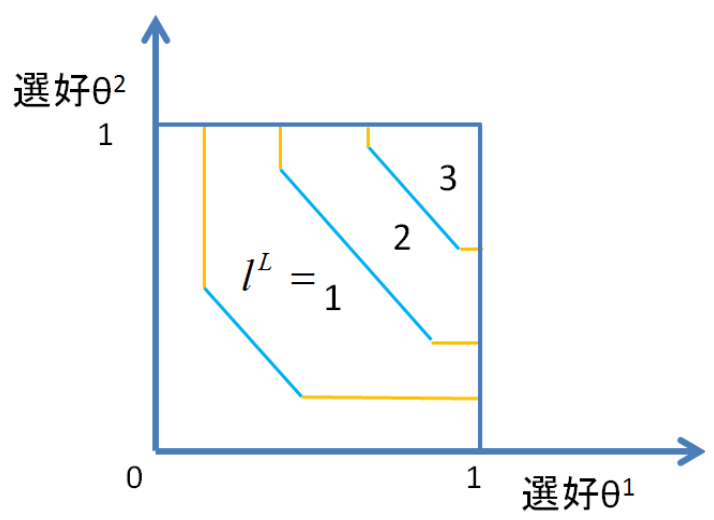

図-3 最適解別の領域（広域媒体）

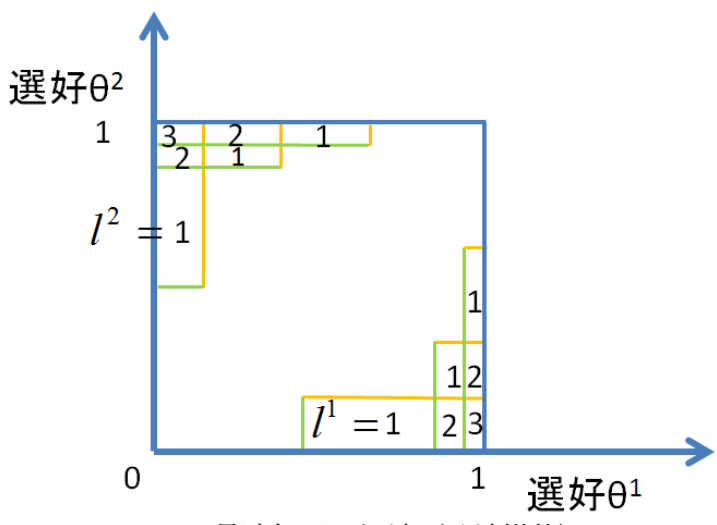

図-4 最適解別の領域（地域媒体）

号は $l^{*}$ を，図-4の左上の領域内の番号は $l^{2 *}$ を示してい る。このとき $l^{1^{*}}>0$ なら $l^{2^{*}}=0$ であり， $l^{2^{*}}>0$ ならば $l^{l^{*}}=0$ であることに注意したい. なお，地域媒体 $1,2 の$ 均衡解における発信数は, 式(4)おおよ゙(6)に式(13)で求め た $l^{L^{*}}$ を代入することにより容易に求められる.

\section{(3) 総発信数と受信容量の導出}

2(2)節で示したナッシュ均衡と等価な条件では受信率 $\rho^{i}$ を所与としているが，この值は本来は所与のもので はなく，計算により内生的に定まるものである， $\rho^{i}$ の 定義（式(1)）に含まれるもののうち，外生的なものは 分子の受信容量 $\phi^{i}$ であり, 分母（総発信数）は内生的
に定まる．受信容量を外生的なものとして均衡解を求め るためには, $\rho^{i}$ を与えて均衡解を計算したのちに, 総 発信数を計算し，それを用いて $\phi^{i}$ を逆算し，その $\phi^{i}$ が 先に与えた受信容量と等しくなるように $\rho^{i}$ を調整する 必要がある. なおこの計算過程は, 本研究独自のもので はなく, Anderson \& de Plama9)の論文を踏襲している.

総発信数を求めるためには，それぞれの媒体の最大発 信数 $\mathbf{K}=\left(k^{1}, k^{2}, k^{L}\right)$ を計算する必要がある. 広域媒体を 最大限に活用する企業は選好 $\boldsymbol{\theta}=(1,1)$ を持つ企業である ことは2(2)節の解析により明らかである。よって $k^{L}=l^{L}(1,1)$ である. 同様に $k^{1}=l^{1}(1,0), k^{2}=l^{2}(0,1)$ で ある. 図-3より $n^{L}$ については $A_{L}\left(l^{L}\right)$ の面積を $l^{L}=1 \ldots k^{L}$ の範囲で合計したものと等しい. 地域媒体の総発信数 $n^{i}$ についても図-4で示される四角形の面積を $l^{1}=1 \ldots k^{1}$ で合計すればよい.

所与の $\rho^{i}$ から計算された $n^{i}$ と $n^{L}$ を用いて求められる 受信容量を

$$
\phi^{i^{*}}=\rho^{i}\left(n^{i}+n^{L}\right)
$$

と定義し，これが所与の $\phi^{i}$ とできるだけ近くなるよう な $\rho^{i}$ を探す. 計算は数值的に行う. 受信率 0 から 1 の範 囲を100×100メッシュに区切り，

$$
e=\sqrt{\left(\phi^{1 *}-\phi^{1}\right)^{2}+\left(\phi^{2^{*}}-\phi^{2}\right)^{2}}
$$

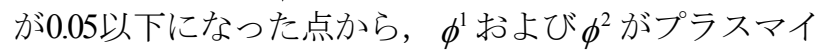
ナス0.05の範囲内で誤差が最小となる点を均衡解の近傍

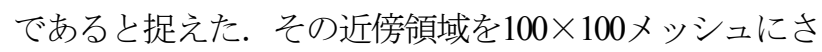
らに細分化して探索し, 誤差が最小になった点を近似的 な均衡解と見な寸。 なお, Anderson \& de Palma 9)でも指摘 されているが，今回の問題においては $\phi^{i}$ に対して均衡 解は一意になるとは限らない（ただし， $\rho^{i}$ を決めれば 唯一に定まる）。選好（は100×100メッシュに区切って 計算を行った。 また各媒体における総発信数は日のメッ シュの四隅に位置する企業の発信数を平均して面積を乗 算することで近似的に求めた。

\section{3. 数値計算}

\section{(1) 与えるパラメータ}

構築したモデルにパラメータを4通り与えて均衡解の 比較を行う，解釈を容易にするために，パラメータは複 数均衡が発生しないものを与えた. 表 1 に各ケースのパ ラメータを示す. case 0 および casel では広域媒体の料金 を広域媒体が利用されないほどに高く与えた。広域媒体 の料金を低くした case2 および case3 と比較することで広 域媒体の存在が均衡に与える影響を分析できる.

casel では case 0 に比へて地域媒体の広告料金を増加さ せている. Anderson \& de Palma9 は媒体の対象範囲を考慮 しないモデルにおいて，一定の条件下でパレート改善を 実現する料金上昇を示している。情報混雑状態では発信 


\begin{tabular}{|c|c|c|c|c|c|c|c|}
\multicolumn{10}{c|}{ 表-1 与えたパラメータ } \\
\hline & $\phi^{1}$ & $\phi^{2}$ & $\bar{\pi}^{1}$ & $\bar{\pi}^{2}$ & $\gamma^{1}$ & $\gamma^{2}$ & $\gamma^{L}$ \\
\hline case0 & 0.81 & 0.81 & 2 & 2 & 0.1 & 0.1 & 100 \\
\hline case1 & 0.81 & 0.81 & 2 & 2 & 0.4 & 0.4 & 100 \\
\hline case2 & 0.81 & 0.81 & 2 & 2 & 0.1 & 0.1 & 0.19 \\
\hline case3 & 0.81 & 0.81 & 2 & 2 & 0.4 & 0.4 & 0.19 \\
\hline
\end{tabular}

を行っている企業の数が消費者の受信容量を下回る時が ある．容量が十分にも関わらず情報混雑が発生する原因 は，潜在的に発信しうる企業（例えば $\gamma^{1} / \rho^{1}>\pi^{1} \theta^{1}$ $>\gamma^{1}, \theta^{2}=0$ を満たす企業）が存在するためである. 容 量が十分な状況では，発信を行っている企業の数が減少 しないぎりぎりまで広告料金を上昇させることで潜在的 な企業を締め出すことができる，同時に情報混雑の解消 とパレート改善が実現されることを Anderson \& de Palma9" は示した. Anderson \& de Palma9"にならい, casel の $\gamma^{i}$ は case0 の均衡における潜在的な企業を排除する $\gamma^{i} / \rho^{i}$ を 与えた。広域媒体が考慮されていない場合，この料金が 導く均衡では以前に比べ発信を行っていた企業全ての利 潤が向上し，発信していなかった企業は現状維持（発信 数 0 のまま）となる.また複数回の発信を行う企業が存 在せず，受信容量も無駄にならない.

case1 と比較して広域媒体が利用されている場合を考 えるため, case2 には $\gamma^{1}+\gamma^{2}>\gamma^{L}$ となる（casel と異な る） $\gamma^{L}$ をええた. case3 では case2 のパラメータから広 域媒体の料金を据え置いて地域媒体の料金のみを上昇さ せた. 上昇幅は case 0 から casel の上昇幅と同じとした. この case3 の料金上昇は広域媒体の存在を無視して地域 媒体の料金を上昇させた場合を想定している.

\section{(2) 均衡の比較}

この節の目標は広域媒体が存在した場合としない場合 の，地域媒体の料金上昇の影響を見ることである。なお 結果は与えたパラメータに依存するため, 可能性を示寸 ことは出来ても一般的な主張にはならない.

図-5 に各 case における各企業の地域 1 への発信数 $\left(l^{1}(\boldsymbol{\theta})+l^{L}(\boldsymbol{\theta})\right)$ の分布を示した. 横軸が地域 1 への選好 $\theta^{1}$ ，縦軸が地域 2 への選好 $\theta^{2}$ である. 今回与えたパラ メータは対称であり, かつ複数均衡が発生しない，その ため地域 2 の発信数分布は地域 1 のものと 45 度線に 対して線対称となる.

表-2 の case0 と casel を比較すると Anderson \& de Palma ${ }^{9}$ が示した通り，受信率がいずれの地域でも改善している. しかし case2 と case3 を比較すると逆に混雑は悪化してい る.このことは，例えば広域媒体の存在を無視した各地 域媒体一の課税のような政策は情報混䧱を悪化させる場 合があることを示唆する．表-3には総便益や総費用， 地域1への発信(case 0$)$

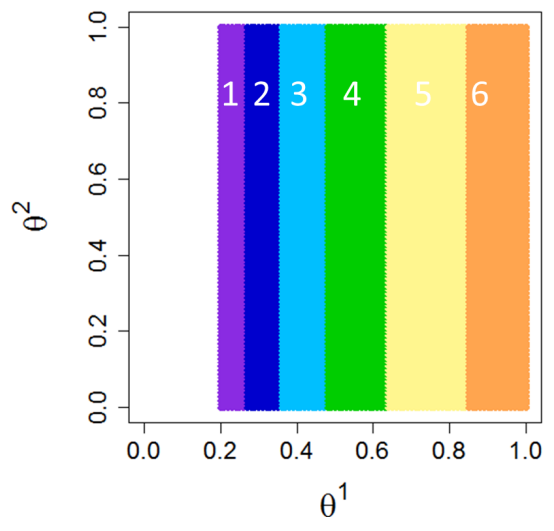

地域1への発信(case 1$)$

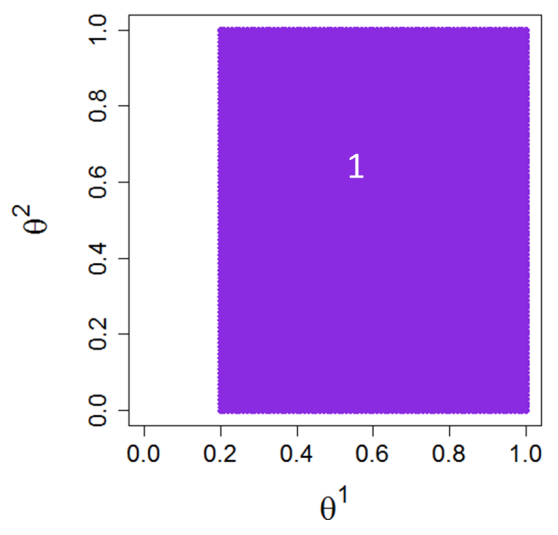

地域1への発信(case 2 )

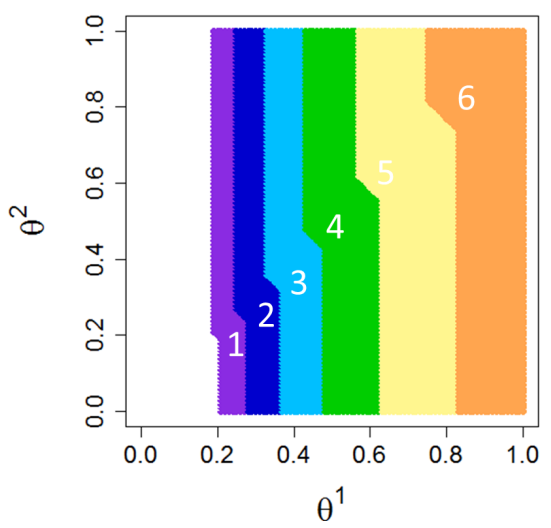

地域1^の発信(case 3 )

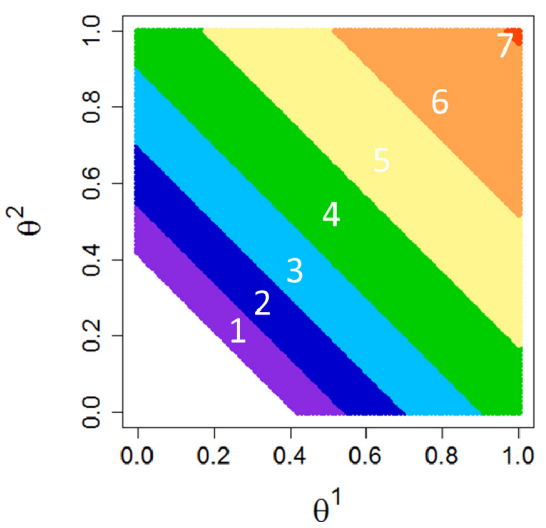

図-5 各caseの発信数分布 
表-2 発信数と受信率

\begin{tabular}{|c|c|c|c|c|c|}
\hline & $\rho^{1}$ & $\rho^{2}$ & $n^{1}$ & $n^{2}$ & $n^{L}$ \\
\hline case0 & 0.2508 & 0.2508 & 3.23 & 3.23 & 0 \\
\hline case1 & 1 & 1 & 0.805 & 0.805 & 0 \\
\hline case2 & 0.2408 & 0.2408 & 1.096 & 1.096 & 2.271 \\
\hline case3 & 0.2272 & 0.2272 & 0 & 0 & 3.566 \\
\hline
\end{tabular}

表-3 総便益・費用・利潤

\begin{tabular}{|l|l|l|l|}
\hline & 総便益 & 総費用 & 総利潤 \\
\hline case0 & 1.370 & 0.646 & 0.724 \\
\hline case1 & 1.924 & 0.644 & 1.28 \\
\hline case2 & 1.365 & 0.650 & 0.715 \\
\hline case3 & 1.278 & 0.678 & 0.601 \\
\hline
\end{tabular}

その合計である総利潤の值を載せている， case0 から casel にかけて企業の総利潤は改善される。総費用があ まり変化していないことは料金上昇と発信数の減少がほ ぼ釣り合っていることに起因する．ここで総利潤の変化 には料金上昇によって広告料金を収受する主体が回収し た分および消費者の利潤の変化が含まれていない．前者 は混雑を解消することで生まれた社会的な余剩である. 後者は受信する情報が重複しないことの影響であり，消 費者にとっての情報の価值が正であれば正になる。情報 の価值がよほど大きな負の值を取らないかぎり，社会的 余剰は増加すると考えるべきである，逆に case2 から case3 にかけての変化は, 図-6 で示すとおり, 企業にと つてパレート劣位である. 図-6 は縦軸に利潤の変化, 横軸に地域 1 の選好を取っている. 地域 2 への選好が 代表值 $(0,0.25,0.5,0.75,1)$ を取るものについて曲線で示し た. グラフに乗せていない企業も含め全企業の利潤（両 地域からの合計）が悪化する。この結果は一部媒体のみ の料金上昇は両地域で活動する企業にとってさえ負の影 響をもたらす場合があることを示唆している.

情報偏在の傾向を見るために，情報が受信される確率 である認識率 $\left(=1-F\left(l^{i}, l^{L}, \rho^{i}\right)\right)$ の比較を行う。図-7 は料金上昇前後（前：case2, 後 : case3）の認識率変化 を描いている．左上部分が上昇し下部中央が下落してい る. 発信数分布の図からも明らかだが，各地域媒体の料 金上昇は各企業のそれぞれの地域への選好と地域内での 認識率の相関を弱める. これは地域固有の企業が認識さ れにくくなることを意味する.

次に広域媒体を考慮した場合としなかった場合の料金 上昇 (政策) による認識率の変化の差 (case0 から casel への変化と case2から case3 間への変化の差）を表したも のが図-8 である。図-8 から広域媒体を考慮した場合と 考慮しなかった場合の料金上昇の影響が全く異なること



図-6 case2から 3に変えたときの料金上昇による 企業の利潤変化

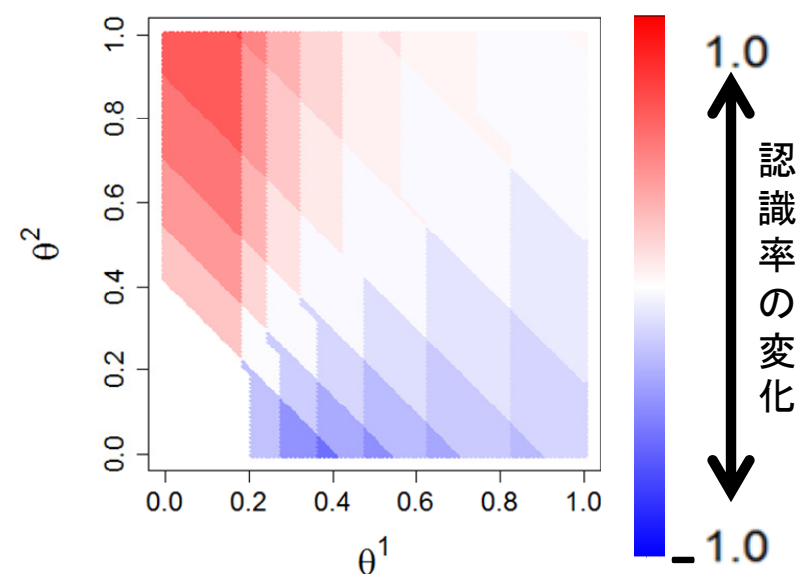

図-7 case2から 3に変えたときの地域 1 における 認識率の変化



図-8 case0 から 1 および case2 から 3 間の地域 1 における 認識率変化の差 




図-9 式(4)，(7)，(8)の交点

がわかる，広域媒体を考慮していない場合，料金上昇は 地域内企業（比較的地域への選好が高い企業）の認知度 を上昇させる，しかし，広域媒体を考慮した場合，同じ 料金上昇が地域内企業の認知度を低下させ，地域外企業 の認知度を上げる結果につながっている．この結果は以 下のように解釈できる．まずどちらの場合も料金上昇に よって，地域内の潜在的な企業が締め出される，広域媒 体が存在しない場合はそのまま混雑が解消され，地域内 の企業の知名度は上昇する。広域媒体が存在する場合は 混雑が緩和され，魅力的になった各地域に対して，（比 較的）他地域と関係の強い企業の発信が広域媒体を経由 して流入することになる．同時に地域内の企業は料金上 昇により発信を控える. 結果的に地域内の選好と認識率 の相関が薄くなる.

現実には広域を対象にした媒体が存在しないことは考 えにくい. 地域内の媒体や企業に効力を持つ混雑緩和の 施策が外部の発信を呼び込ならば，これは地域内企業 に不利な方向に情報の偏在を強化することを意味する. 今回の結果は地域内のみで情報混雑の対策を行うことが 難しいことを示唆している.

\section{4. 広域媒体を考慮した料金上昇政策}

前章では広域媒体を考慮しないような料金上昇を試し， 好ましくない結果につながった，その代替的な政策とし て，ここでは包括的な料金上昇によって，限定的な条件 下ではパレート改善が可能なことを示す.

式(4)，(7)，(8)を用いると，地域 1 において少なくとも 1 回発信を行う企業が満たす選好を求めることができる. 料金上昇によって，この選好の範囲を減らさずに，発信 を行いうる潜在的な企業（例えば $\gamma^{1} / \rho^{1}>\pi^{1} \theta^{1}>\gamma^{1}$ かつ $\theta^{2}=0$ を満たす企業）を締め出すことが出来ればパレ 一ト改善が達成される. 領域の変動を見るために, 式 (4)，(7)，(8)の等式が満たされる状態の選好に注目する. 前提として料金上昇前に発信を行っている企業の数が受 信容量より少ないことを仮定する.
式(4)，(7)，(8)が示寸領域の境界線は

$$
\begin{aligned}
& \theta_{\mathrm{A}}^{1}=\frac{\gamma^{1}}{\bar{\pi}^{1} F\left(0,0, \rho^{1}\right) \rho^{1}} \\
& \theta_{\mathrm{A}}^{2}=\frac{\gamma^{L}-\gamma^{1}}{\bar{\pi}^{2} \rho^{2} F\left(0,0, \rho^{2}\right)}
\end{aligned}
$$

で交わる．この点 $\mathrm{A}$ （図-9）が料金上昇後（混雑解消 後）も不動であるとは，料金上昇後の料金 $\hat{\gamma}^{1}, \hat{\gamma}^{2}, \hat{\gamma}^{L}$ が

$$
\begin{gathered}
\theta_{\mathrm{A}}^{1}=\frac{\gamma^{1}}{\bar{\pi}^{1} F\left(0,0, \rho^{1}\right) \rho^{1}}=\frac{\hat{\gamma}^{1}}{\bar{\pi}^{1}} \\
\theta_{\mathrm{A}}^{2}=\frac{\gamma^{L}-\gamma^{1}}{\bar{\pi}^{2} \rho^{2} F\left(0,0, \rho^{2}\right)}=\frac{\hat{\gamma}^{L}-\hat{\gamma}^{1}}{\bar{\pi}^{2}}
\end{gathered}
$$

を満たすことを意味する.これより

$$
\begin{gathered}
\hat{\gamma}^{1}=\frac{\gamma^{1}}{\rho^{1}} \\
\hat{\gamma}^{L}-\hat{\gamma}^{1}=\frac{\gamma^{L}-\gamma^{1}}{\rho^{2}} \\
\Leftrightarrow \hat{\gamma}^{L}=\hat{\gamma}^{1}+\frac{\gamma^{L}-\gamma^{1}}{\rho^{2}}=\frac{\gamma^{1}}{\rho^{1}}+\frac{\gamma^{L}-\gamma^{1}}{\rho^{2}}
\end{gathered}
$$

が導ける．同様の議論を点 B（図-9）に適用して

$$
\begin{gathered}
\hat{\gamma}^{2}=\frac{\gamma^{2}}{\rho^{2}} \\
\hat{\gamma}^{L}-\hat{\gamma}^{2}=\frac{\gamma^{L}-\gamma^{2}}{\rho^{1}} \\
\Leftrightarrow \hat{\gamma}^{L}=\hat{\gamma}^{2}+\frac{\gamma^{L}-\gamma^{2}}{\rho^{1}}=\frac{\gamma^{2}}{\rho^{2}}+\frac{\gamma^{L}-\gamma^{2}}{\rho^{1}}
\end{gathered}
$$

も導出できる. 式(21)と式(23)から

$$
\begin{aligned}
& \hat{\gamma}^{L}=\frac{\gamma^{2}}{\rho^{2}}+\frac{\gamma^{L}-\gamma^{2}}{\rho^{1}}=\frac{\gamma^{1}}{\rho^{1}}+\frac{\gamma^{L}-\gamma^{1}}{\rho^{2}} \\
& \Leftrightarrow \gamma^{L}\left(\frac{1}{\rho^{1}}-\frac{1}{\rho^{2}}\right)=\left(\gamma^{1}+\gamma^{2}\right)\left(\frac{1}{\rho^{1}}-\frac{1}{\rho^{2}}\right)
\end{aligned}
$$

となる．ここで $\gamma^{1}+\gamma^{2}>\gamma^{L}$ なので $\rho^{1}=\rho^{2}$ である.こ れより発信を行う企業を変化させずにパレート改善を実 現するような，料金上昇には料金上昇前の均衡において 受信率が等しいこと $\left(\rho^{1}=\rho^{2}\right)$ が求められる. この条件 が成立する時については, 以下に示すとおり, 全ての企 業の利潤が増加するかせいぜい等しい。

この証明は Anderson \& de Palma ${ }^{9}$ の証明に準ずる.もし $l^{L}=0$ ならばAnderson \& de Palmaの証明と同一の式にな る. それ以外の場合, 地域媒体は片方が常に 0 回発信に なるので $l^{2^{*}}=0, l^{L^{*}}>0$ を仮定する. まず料金上昇後 の均衡解において広域の媒体で少なくとも 1 回発信を行 う企業のうち， $l^{l^{*}}=0$ の企業の利潤変化を考える.

$$
\begin{aligned}
& \bar{\pi}^{1} \theta^{1}+\bar{\pi}^{2} \theta^{2}-\hat{\gamma}^{L} \\
& \geq \bar{\pi}^{1} \theta^{1}\left[1-\left(1-\rho^{1}\right)^{l^{L^{*}}}\right]+\bar{\pi}^{2} \theta^{2}\left[1-\left(1-\rho^{2}\right)^{l^{L^{*}}}\right] \\
& -\gamma^{L} l^{L^{*}}
\end{aligned}
$$

であれば料金上昇によって利潤が増加している．整理す 
ると，

$$
\begin{aligned}
& \bar{\pi}^{1} \theta^{1}\left(1-\rho^{1}\right)^{L^{L^{*}}}+\bar{\pi}^{2} \theta^{2}\left(1-\rho^{2}\right)^{l^{L^{*}}} \geq \hat{\gamma}^{L}\left(1-\rho^{1} l^{L^{*}}\right) \\
& \Leftrightarrow\left(\bar{\pi}^{1} \theta^{1}+\bar{\pi}^{2} \theta^{2}\right)\left(1-\rho^{1}\right)^{l^{*}} \geq \hat{\gamma}^{L}\left(1-\rho^{1} L^{L^{*}}\right)
\end{aligned}
$$

となる。境界線の交点が不動なので, 式(8)から $l^{L^{*}}>0$ の企業は少なくとも $\bar{\pi}^{1} \theta^{1}+\bar{\pi}^{2} \theta^{2} \geq \gamma^{L}$ であり， $l^{L^{*}}>1$ で は $\left(1-\rho^{1}\right)^{l^{*}}>\left(1-\rho^{1} l^{L^{*}}\right)$ である. したがって式(25)が成 立寸る. 次に $l^{l^{*}}>0$ の企業の利潤変化を考える.

$$
\begin{aligned}
& \quad \bar{\pi}^{1} \theta^{1}+\bar{\pi}^{2} \theta^{2}-\hat{\gamma}^{L} \\
& \geq \bar{\pi}^{1} \theta^{1}\left[1-\left(1-\rho^{1}\right)^{l^{*}+l^{*}}\right]+\bar{\pi}^{2} \theta^{2}\left[1-\left(1-\rho^{2}\right)^{l^{*}}\right] \\
& -\gamma^{1} l^{l^{*}}-\gamma^{L} l^{L^{*}} \\
& \Leftrightarrow \bar{\pi}^{1} \theta^{1}\left(1-\rho^{1}\right)^{l^{*}+l^{L^{*}}}+\bar{\pi}^{2} \theta^{2}\left(1-\rho^{2}\right)^{l^{L^{*}}} \\
& \geq \hat{\gamma}^{L}\left(1-\rho^{1} l^{L^{*}}\right)-\gamma^{1} l^{l^{*}} \\
& l^{l^{*}, l^{L^{*}}}>0 \text { より式(4), (7)を用いると }
\end{aligned}
$$

$$
\begin{aligned}
& \gamma^{1} \frac{\left(1-\rho^{1}\right)}{\rho^{1}}+\left(\gamma^{L}-\gamma^{1}\right) \frac{\left(1-\rho^{1}\right)}{\rho^{1}} \geq \hat{\gamma}^{L}\left(1-\rho^{1} l^{L^{*}}\right)-\gamma^{1} l^{1^{*}} \\
& \Leftrightarrow\left(1-\rho^{1}\right)+\rho^{1} \frac{\gamma^{1}}{\gamma^{L}} l^{1^{*}}>\left(1-\rho^{1} l^{L^{*}}\right)
\end{aligned}
$$

ここで $\left(1-\rho^{1}\right)>\left(1-\rho^{1} L^{L^{*}}\right)$ なので, 包括的な料金上昇 によってパレート改善が実現される.

\section{5. 結論}

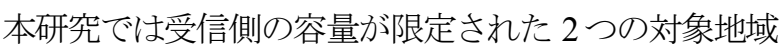
に対する $3 つ の$ 媒体による企業の広告発信を描写するモ デルを提案した. モデルを用いて Anderson \& de Palma'に よって提案された料金上昇に対して媒体の異質性（対象 となる範囲）を考慮した場合の影響を検討した. 数值計 算から地域媒体のみの料金上昇は情報混雑を悪化させ， 同時に地域内のみで提供されるサービスの情報をかき消 してしまう恐れがあることを示した．また各媒体の料金 バランスを調整した料金上昇は Anderson \& de Palma'の主 張同様, 混雑を改善させ無駄な発信が発生しないことを 限定的な条件で示した．今回の結果は広告における情報 混雑の対策を媒体の対象範囲の異質性を考慮せずに扱う
ことが難しいことを示唆している.

情報の偏在が発生するメカニズムの部分的な説明を試 みるために, 本研究では広告制度を数理的に扱った. 情 報混雑状態では発信から利益を挙げられる企業が埋もれ てしまう可能性がある。 そのような情報の偏在緩和のた めの手段として広告の利用を考える時，対象範囲の異質 性や重複を無視して適切な政策を行うことは難しいだろ う。地域の商店街や観光産業の復興を図る上で，当該地 域を超えた大きな目線での政策も有望かもしれない.

モデルを構築する上で強い仮定を置いており，例えば 広告媒体の異質性は対象範囲に限られない，対象範囲の 扱いも本研究の離散的な扱いは改良の余地がある. 他に 今後の課題として受信容量や企業の便益分布の内生化と 仮定の妥当性検証などが挙げられる.

\section{参考文献}

1) 林和良, 井料隆雅 : 地理的制約のあるサービスの普 及に関寸る実証分析, 平成 25 年度土木学会関西支部 年次学術講演会講演概要集, CD-ROM, 2013.

2) Stigler, G. J. : The economics of information, Journal of Political Economy, Vol. 69, No. 3, pp. 213-225, 1961.

3) Nelson, P. : Information and consumer behavior, Journal of Political Economy, Vol. 78, No. 2. pp. 311-329, 1970.

4) Bagwell, K. : The economic analysis of advertising, In: Handbook of Industrial Organization, Vol. 3, pp. 17011844, 2007.

5) Eppler, M. J. and Mengis, J. : The concept of information overload: a review of literature, The Information Society: An International Journal, Vol. 20, pp. 325-344, 2004.

6) Van Zandt, T. : Information overload in a network of targeted communication, The RAND Journal of Economics, Vol. 35, pp. 542-560, 2004.

7) Anderson, S. P. and de Palma, A. : Information congestion, The RAND Journal of Economics, Vol. 40, pp. 688-709, 2009.

8) Anderson, S. P. and de Palma, A. : Competition for attention in the information (overload) age, The RAND Journal of Economics, Vol. 43, pp. 1-25, 2012.

9) Anderson, S. P. and de Palma, A. : Shouting to be heard in advertising, Management Science, Vol. 59, pp. 1545-1556, 2013.

(2015. 2. 27 受付) 


\section{SPATIAL LOCALITY OF ADVERTISING MEDIA \\ AND INFORMATION ASYMMETRY \\ —AN ANALYSIS BY A MODEL WITH TWO AREAS AND THREE MEDIA-}

\section{Ryoji JINUSHI and Takamasa IRYO}

The fact that information on local services (e.g. local shops and restaurants) is not known by potential consumers affects their behaviour. Advertising may help remedy such information asymmetry and promote local shops in towns. An existing economic model of advertising, including limited consumer attention, is extended by considering the range of the affected advertising media area. The numerical analysis focuses on a pricing scheme only to local advertising media. Results implies such a scheme can create problematic case in which the distribution of information on local services is suppressed. On the other hand, in a limited case, it is proven that a Pareto-improving pricing scheme exists. 